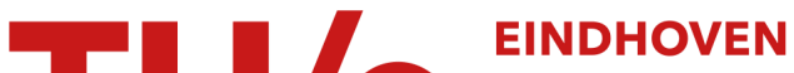 UNIVERSITY OF TECHNOLOGY
}

\section{Hydration kinetics study of class $\mathrm{G}$ oil-well cement and olivine nano-silica mixtures at $20-60{ }^{\circ} \mathrm{C}$}

\section{Citation for published version (APA):}

Quercia Bianchi, G., \& Brouwers, H. J. H. (2015). Hydration kinetics study of class G oil-well cement and olivine nano-silica mixtures at $20-60^{\circ} \mathrm{C}$. In K. Sobolev, \& S. P. Shah (Eds.), Nanotechnology in Construction:

Proceedings of NICOM5 (pp. 179-185). Springer. https://doi.org/10.1007/978-3-319-17088-6_22

DOI:

10.1007/978-3-319-17088-6_22

Document status and date:

Published: 01/01/2015

\section{Document Version:}

Accepted manuscript including changes made at the peer-review stage

\section{Please check the document version of this publication:}

- A submitted manuscript is the version of the article upon submission and before peer-review. There can be important differences between the submitted version and the official published version of record. People interested in the research are advised to contact the author for the final version of the publication, or visit the $\mathrm{DOI}$ to the publisher's website.

- The final author version and the galley proof are versions of the publication after peer review.

- The final published version features the final layout of the paper including the volume, issue and page numbers.

Link to publication

\section{General rights}

Copyright and moral rights for the publications made accessible in the public portal are retained by the authors and/or other copyright owners and it is a condition of accessing publications that users recognise and abide by the legal requirements associated with these rights.

- Users may download and print one copy of any publication from the public portal for the purpose of private study or research.

- You may not further distribute the material or use it for any profit-making activity or commercial gain

- You may freely distribute the URL identifying the publication in the public portal.

If the publication is distributed under the terms of Article 25fa of the Dutch Copyright Act, indicated by the "Taverne" license above, please follow below link for the End User Agreement:

www.tue.nl/taverne

Take down policy

If you believe that this document breaches copyright please contact us at:

openaccess@tue.nl

providing details and we will investigate your claim. 


\title{
Hydration Kinetics Study of Class G Oil-Well Cement and Olivine Nano-silica Mixtures at $20-60{ }^{\circ} \mathrm{C}$
}

\author{
G. Quercia Bianchi, H.J.H. Brouwers, and K. Luke
}

\begin{abstract}
In this study the heat evolution of standard density slurries $\left(1.89 \mathrm{~g} / \mathrm{cm}^{3}\right)$ of Class G oil-well cement and olivine nano-silica additions (0.5-2.0\% bwoc), cured under different temperatures $\left(20-60{ }^{\circ} \mathrm{C}\right)$ and atmospheric pressure, were examined by isothermal calorimetry. Under isothermal and isobaric conditions, the dependency of cement hydration kinetics on curing temperature is related to the activation energy of the cementing slurry. The estimated apparent activation energy of the different slurries with olivine nano-silica varies from 38 to $44 \mathrm{KJ} / \mathrm{mol}$ using a dynamic method, at the temperature range of $20-60{ }^{\circ} \mathrm{C}$. It is demonstrated that the addition of olivine nano-silica increases the rate and the heat of hydration of oil-well slurries. These effects are temperature dependent. Finally, comparable hydration degrees were obtained between slurries containing $0.5 \%$ bwoc of olivine nano-silica and $10 \%$ bwoc of oil-well grade micro-silica $(\mathrm{mS})$.
\end{abstract}

Keywords Nano-silica $\bullet$ Olivine $\bullet$ Oil-Well $\bullet$ Cement $\bullet$ Hydration

\section{Introduction}

In oil and gas well construction, one of the most critical processes is that of primary well cementing. Primary well cementing is the process of placing cement in the annular space between the casing and the formation exposed to the drilled wellbore, with the major function to provide zonal isolation. Nano-materials, in particular colloidal silica, are known to improve on the properties of oil well cementing

\footnotetext{
G. Quercia Bianchi $(\bowtie)$

Eindhoven University of Technology, Eindhoven, The Netherlands

Trican Well Service Ltd, Calgary R\&D Centre, Calgary, AB, Canada

e-mail: g.quercia@tue.nl; gquercia@trican.ca

http://www.trican.ca; http://www.tue.nl

H.J.H. Brouwers

Eindhoven University of Technology, Eindhoven, The Netherlands

K. Luke

Trican Well Service Ltd, Calgary R\&D Centre, Calgary, AB, Canada
} 
compositions [1]. Several methods are used to produce nano-silica, with the two most important commercial processes being neutralization of sodium silicate solutions with acid (colloidal silica) and flame hydrolysis (pyrogenic silica) [2]. These processes are expensive due to the price of the raw materials and the energy requirements involved. As a result of this a more economical method to produce nano-silica has been developed, based on dissolution of olivine $(\mathrm{OnS})$ in acid. Published results [1] on the hydration kinetics and rheological tests of OPC cement pastes with OnS have shown its potential use as an additive to control the viscosity of the slurry, provide thixotropic behavior and possibility to enhance the early compressive strength. However, the effects of adding OnS to a Class G oil-well cement compared to a construction Type 1 cement as well as curing under conditions found typically in well cementing operations have not been studied to date. This paper reports on the use of isothermal calorimetry, as a first approach, to elucidate the effect of OnS on Class G cement slurries.

\section{Materials and Experimental Methods}

An OnS dispersion (synthesized at the pilot scale [1]) with $10.0 \mathrm{wt} \%$ solids, equivalent $\mathrm{SiO}_{2}$ content of $99.1 \mathrm{wt} \%$ and a specific surface area measured by BET method of $399 \mathrm{~m}^{2} / \mathrm{g}$ was used. The oil-well cement was a Class G HSR grade as classified by ISO 10426-1 [3]. Oil-well grade micro-silica $(\mathrm{mS})$ with a $94.0 \mathrm{wt} \%$ of $\mathrm{SiO}_{2}$, density of $2.3 \mathrm{~g} / \mathrm{cm}^{3}$ and BET specific surface area of $19 \mathrm{~m}^{2} / \mathrm{g}$ was used for comparison with the OnS dispersion. Finally, a commercial dispersant based on modified polycarboxylate ether (PCE-type superplasticizer) with $35 \%$ solids content and a density of $1.095 \mathrm{~g} / \mathrm{cm}^{3}$ was used for the calorimetric study. Distilled water was used in all experiments. A total of eight oil-well cement slurries with a normal density of $1.89 \mathrm{~g} / \mathrm{cm}^{3}(15.79 \mathrm{lbm} / \mathrm{gal})$ were prepared according to the designs shown in Table 1. Slurry preparation consisted of adding dispersant and OnS or powder micro-silica to water in a high energy (600 W) hand blender (Philips HR 1363) at 20 s intervals. This was followed by addition of the cement over a $15 \mathrm{~s}$ period and then continuing mixing for an additional $1 \mathrm{~min}$ to obtain a homogeneous slurry. The formulated slurries were studied using an isothermal calorimeter (TAM® Air TA Instruments) at 20,40 and $60{ }^{\circ} \mathrm{C}$ over a period of $48 \mathrm{~h}$.

Table 1 Slurry designs used for hydration kinetic studies (density $1.89 \mathrm{~g} / \mathrm{cm}^{3}$ )

\begin{tabular}{l|l|l|l|l|l|l|l|l}
\hline Materials & Ref-1 & CS-1 & CS-2 & CS-3 & CS-4 & CS-5 & CS-6 & CS-7 \\
\hline OnS-15 $(\% \text { bwoc) })^{\mathrm{a}}$ & 0 & 0.5 & 1.0 & 1.5 & 2.0 & 0 & 0 & 0 \\
\hline Micro-silica $(\%$ bwoc) & 0 & 0 & 0 & 0 & 0 & 1.0 & 2.0 & 10.0 \\
\hline Class G HSR $(\%)$ & 100 & 100 & 100 & 100 & 100 & 100 & 100 & 100 \\
\hline Water $(\%$ bwoc) & 44 & 44.1 & 44.3 & 44.4 & 44.6 & 43.7 & 43.5 & 41.3 \\
\hline Dispersant $(\mathrm{gal} / \mathrm{sk}) \times 100$ & 6 & 6 & 6 & 6 & 6 & 6 & 6 & 6 \\
\hline w/b & 0.44 & 0.44 & 0.44 & 0.44 & 0.45 & 0.44 & 0.44 & 0.41 \\
\hline
\end{tabular}

${ }^{\text {aEquivalent }} \mathrm{SiO}_{2}$ content. Sk: 1 cement sack $=94 \mathrm{lbm}(42.64 \mathrm{~kg})$ 
The progress of the hydration of the cement slurries was quantified by the hydration degree $(\alpha)$, which varies from 0 to 1 . For this study, the hydration degree is estimated according to [4] as the ratio of heat evolved at time t to the total amount of heat available $\left(\mathrm{Q}_{\max }\right)$. The value $\mathrm{Q}_{\max }$ was calculated according to [5] using the cement composition and amount and type of silica. The maximum heat of olivine nano-silica or micro-silica was assumed to be equal from the amount of amorphous $\mathrm{SiO}_{2}$ in both silica types (amount to $780 \mathrm{~J} / \mathrm{g}$ according to [6]). The activation energy (Ea) was estimated using two different methods. The first method applied was considering a first order reaction rate (Arrhenius-type) expression as follows:

$$
k=A \cdot e^{\frac{-E a}{R T}}
$$

where $R$ equals the natural gas constant $(8.314 \mathrm{~J} / \mathrm{mol} / \mathrm{K}), T$ equals the temperature in $\mathrm{K}$ at which reaction occurs, $k$ equals the rate of heat flow evolution $(d H / d t), A$ equals the proportionality constant (same units as k), and Ea equals the activation energy $(\mathrm{J} / \mathrm{mol})$. In the present study, $k$ was calculated from the heat flow curves obtained for each slurry tested. It is derived as the slope of the best linear fit during the acceleration period. To quantify the apparent Ea, the methodology described by [7] was applied. The second method applied to determine the activation energy was the incremental reaction rate method. This method considers that the reaction rate is a function of the hydration degree (considering a differential first order rate approximation) [5]. In this method the reaction rate at each point where heat flow evolution was measured at a constant hydration degree. Thus, the activation energy is calculated from the heat rate results according to [8] as follows:

$$
\mathrm{Ea}(\alpha)=R\left[\frac{\mathrm{T}_{1} \mathrm{~T}_{2}}{\mathrm{~T}_{1}-\mathrm{T}_{2}} \ln \left(\frac{\frac{d \alpha_{1}}{d t}}{\frac{d \alpha_{2}}{d t}}\right)\right]
$$

in which $\mathrm{R}$ equals the natural gas constant, $\mathrm{T}_{1}$ and $\mathrm{T}_{2}$ are the curing temperatures (in $\mathrm{K})$ and $d \alpha_{1} / d t, d \alpha_{2} / d t$ are the rate of hydration at $\mathrm{T}_{1}$ and $\mathrm{T}_{2}$, respectively. For the calculation of the activation energy using the incremental reaction rate method the data at $20-60{ }^{\circ} \mathrm{C}$ was considered.

\section{Results and Discussion}

From the heat flow curves (Fig. 1a) the hydration degree $(\alpha)$ of the different cement slurries studied was calculated (Fig. 1b). It is interesting that the final estimated $\alpha$ of $10 \% \mathrm{mS}$ slurry is the lowest in the tested range of temperatures $\left(20-60{ }^{\circ} \mathrm{C}\right)$. The lowest hydration degree for $10 \% \mathrm{mS}$ is probably caused by the lower w/b ratio (0.41) compared to the others slurries tested $(\mathrm{w} / \mathrm{b}=0.44)$. The higher hydration degree obtained at all tested temperatures confirms again the acceleration effect 
a

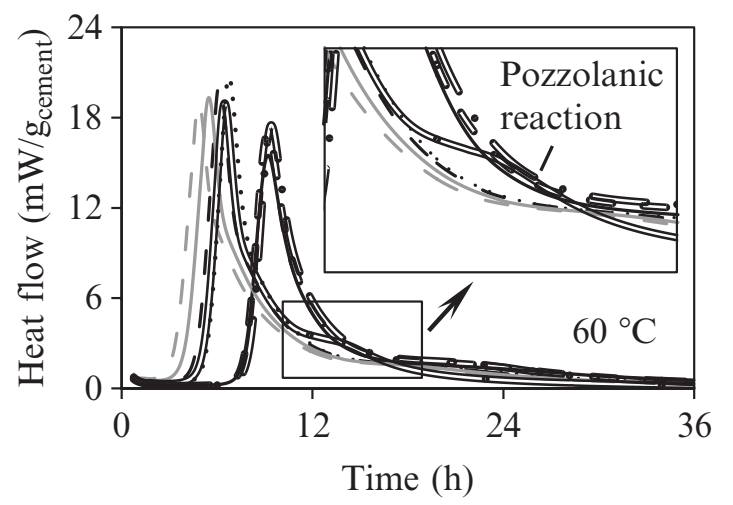

b

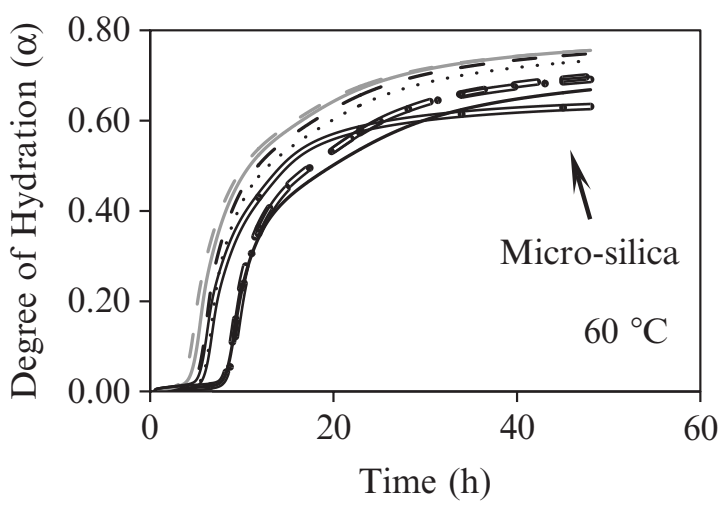

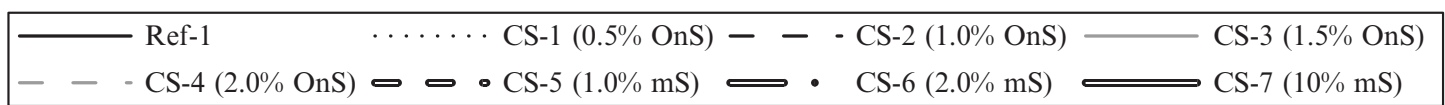

Fig. 1 Examples of obtained results at $60{ }^{\circ} \mathrm{C}$ of the different cement slurries (normal density $\left.1.89 \mathrm{~g} / \mathrm{cm}^{3}\right),(\mathbf{a})$ head flow curves and (b) estimated hydration degree curve

Table 2 Estimated hydration degree $(\alpha)$ for the different cement slurries (normal density $1.89 \mathrm{~g} /$ $\mathrm{cm}^{3}$ ) tested at $20{ }^{\circ} \mathrm{C}, 40{ }^{\circ} \mathrm{C}$ and $60{ }^{\circ} \mathrm{C}$, respectively

\begin{tabular}{|c|c|c|c|c|c|c|c|c|c|}
\hline & & $20^{\circ} \mathrm{C}$ & & & $40^{\circ} \mathrm{C}$ & & & $60^{\circ} \mathrm{C}$ & \\
\hline Slurry & $\begin{array}{l}\alpha \\
(12 \mathrm{~h})\end{array}$ & $\begin{array}{l}\alpha \\
(24 \mathrm{~h})\end{array}$ & $\begin{array}{l}\alpha \\
(48 \mathrm{~h})\end{array}$ & $\begin{array}{l}\alpha \\
(12 \mathrm{~h})\end{array}$ & $\begin{array}{l}\alpha \\
(24 \mathrm{~h})\end{array}$ & $\begin{array}{l}\alpha \\
(48 \mathrm{~h})\end{array}$ & $\begin{array}{l}\alpha \\
(12 \mathrm{~h})\end{array}$ & $\begin{array}{l}\alpha \\
(24 \mathrm{~h})\end{array}$ & $\begin{array}{l}\alpha \\
(48 \mathrm{~h})\end{array}$ \\
\hline Ref-1 & 0.023 & 0.22 & 0.44 & 0.27 & 0.47 & 0.59 & 0.35 & 0.55 & 0.65 \\
\hline CS-1 & 0.026 & 0.28 & 0.48 & 0.37 & 0.54 & 0.66 & 0.48 & 0.64 & 0.73 \\
\hline CS-2 & 0.031 & 0.30 & 0.49 & 0.39 & 0.54 & 0.66 & 0.51 & 0.67 & 0.75 \\
\hline CS-3 & 0.053 & 0.33 & 0.50 & 0.39 & 0.55 & 0.67 & 0.53 & 0.68 & 0.76 \\
\hline CS-4 & 0.089 & 0.35 & 0.50 & 0.39 & 0.55 & 0.67 & 0.54 & 0.68 & 0.76 \\
\hline CS-5 & 0.023 & 0.23 & 0.45 & 0.26 & 0.47 & 0.49 & 0.37 & 0.59 & 0.70 \\
\hline CS-6 & 0.022 & 0.23 & 0.45 & 0.29 & 0.49 & 0.61 & 0.36 & 0.59 & 0.69 \\
\hline CS-7 & 0.028 & 0.27 & 0.42 & 0.30 & 0.45 & 0.58 & 0.43 & 0.59 & 0.63 \\
\hline
\end{tabular}

induced by the OnS additions. In general, the higher the temperature the higher the hydration degree for OnS slurries. Table 2 summarizes the calculated hydration degrees at 12, 24 and $48 \mathrm{~h}$, for all the cement slurries tested. It is possible to observe from the data in this table that a small addition of OnS ( $0.5 \%$ bwoc) has the same effect as $10 \%$ bwoc of micro-silica. Higher $\alpha$ after $12 \mathrm{~h}$ results in cost reductions due to the decrease in waiting time to continue the drilling operations due to cementing operations. Also, operations performed can be easier due to the fact there is no need for additional blending steps of a high percentage of micro-silica.

In cement hydration, multiple reactions take place simultaneously, all of which are affected by temperature. The term apparent activation energy (Ea) is used to represent the average effect of temperature on the combined reactions. The estimated apparent activation energy results obtained for the first method (slope or linear approximation) and the second method (incremental calculation) are summarized 
Table 3 Estimated average activation energy (Ea) of the different cement slurries (normal density $\left.1.89 \mathrm{~g} / \mathrm{cm}^{3}\right)$

\begin{tabular}{l|l|l|l}
\hline & $\begin{array}{l}\text { Slope method } \\
(\mathrm{static})\end{array}$ & $\begin{array}{l}\text { Incremental method } \\
\text { (dynamic) }\end{array}$ & $\begin{array}{l}\text { Incremental method } \\
(\text { dynamic) }\end{array}$ \\
\cline { 2 - 4 } Slurry & $\mathrm{Ea}_{20-40-60}(\mathrm{~kJ} / \mathrm{mol})$ & $\mathrm{Ea}_{20-40}(\mathrm{~kJ} / \mathrm{mol})$ & $\mathrm{Ea}_{40-60}(\mathrm{~kJ} / \mathrm{mol})$ \\
\hline Ref-1 & 63.57 & $38.18 \pm 0.09(39.57)$ & $43.34 \pm 0.05(43.49)$ \\
\hline CS-1 & 67.86 & $38.12 \pm 0.11(38.99)$ & $43.37 \pm 0.14(41.40)$ \\
\hline CS-2 & 64.52 & $38.20 \pm 0.15(39.24)$ & $43.33 \pm 0.06(39.72)$ \\
\hline CS-3 & 60.84 & $38.16 \pm 0.05(39.96)$ & $43.35 \pm 0.10(40.48)$ \\
\hline CS-4 & 58.34 & $38.14 \pm 0.06(37.89)$ & $43.33 \pm 0.07(38.76)$ \\
\hline CS-5 & 64.88 & $38.17 \pm 0.11(39.52)$ & $43.29 \pm 0.11(41.92)$ \\
\hline CS-6 & 67.65 & $38.14 \pm 0.05(38.41)$ & $43.36 \pm 0.04(46.67)$ \\
\hline CS-7 & 63.57 & $38.14 \pm 0.07(35.26)$ & $43.32 \pm 0.07(43.40)$ \\
\hline
\end{tabular}

in Table 3. It is evident from the data presented in Table 3 that the Ea obtained by the slope method is different for all slurries. In the case of the OnS slurries, the Ea increases for 0.5 and $1.0 \%$ bwoc OnS slurries (CS-1 and CS-2) compared to the reference, after that the Ea drops to a minimum of $58.34 \mathrm{~kJ} / \mathrm{mol}$ for $2.0 \% \mathrm{OnS}$ (CS-4). Similar observation, but with lower extent, was made for the slurries with micro-silica $(\mathrm{mS})$. Different interpretations can be made based on the obtained results. First, the drop in the activation energy, in general, confirms the acceleration effect induced by nano-silica particles.

Lower Ea means that the hydration reaction is enhanced or can occur easier. Also, according to [9], reactions with high Ea are very temperature-sensitive. On the contrary, reactions with low Ea are relatively temperature-sensitive. Based on this, it is possible to state that the addition of $\mathrm{OnS}$ and $\mathrm{mS}$ in concentrations lower than $2.0 \%$ bwoc make the hydration reaction of Class G HSR more temperaturesensitive. The increase in the activation energy for small amounts of OnS and $\mathrm{mS}$ is not expected considering the observed acceleration effects. One explanation of this can be found in changes induced by the presence of nano-particles in the stoichiometry, kinetics and mechanism of cement hydration reaction [9]. Cement is composed of a number of different phases that react at different rates, so it is possible that the Ea may vary considerably as with the hydration degree [5]. Furthermore, hydration is initially reaction-rate-limited and becomes diffusion-limited as solid hydration products are formed [10]. For that reason an incremental calculation method was also applied to highlight how Ea is influenced by the progress of hydration (Table 3). The average Ea for slurries with OnS is slightly affected compared to the reference slurry. Nevertheless, considering the instantaneous Ea calculated at very early age ( $\alpha=0.01$ ) which is represented by the values in parenthesis in Table 3, it is possible to observe that the Ea is lower than the reference. This confirms again the role of OnS to decrease the Ea and thus, accelerating the slurry's setting. The same observation is valid for $\mathrm{mS}$ slurries which also decrease Ea. In Table 3 it is also possible to observe that the apparent activation energy varies with the temperature $\left(\mathrm{Ea} 2_{0-}\right.$ $\left.{ }_{40}<\mathrm{Ea}_{40-60}\right)$. According to [8] this variation is not illogical insofar as the Arrhenius 
relation has been established for simple reactions only. This energy represents a constant with chemical significance. In the case of the reaction of cement hydration, it concerns a macroscopic apparent activation energy, which translates to no chemical law at the microscopic level [6]. Further studies [5, 11] attributed the change of Ea with temperature rise. The fast initial hydration caused by high temperature leads to the formation of a thicker and more compact layer of hydration products (changes in microstructure level) around the cement grains that affects the hydration (increasing Ea).

\section{Conclusions}

In this study, the influence of olivine nano-silica $(\mathrm{OnS})$ in the hydration behavior of oil-well Class G HSR cement has been addressed. Cementing mixes were tested using available calorimetric methods. Modifications in the cement degree of hydration and activation energy have been observed. The test results demonstrated that the temperature, specific surface area (concentration) and type of amorphous silica (OnS vs. $\mathrm{mS}$ ) for the given $\mathrm{w} / \mathrm{b}$ ratio are the controlling parameters. Based on these observations it is concluded that the OnS acts as an accelerating agent in well cementing slurries. Finally, comparable hydration degrees were obtained between slurries containing $0.5 \%$ bwoc of OnS and $10 \%$ bwoc of oil-well grade $\mathrm{mS}$.

\section{References}

1. Quercia, G. (2014). Application of nano-silica in concrete (pp. 1-328). PhD dissertation, Eindhoven University of Technology, Eindhoven

2. Lazaro, A., Brouwers, H. J. H., Quercia, G., \& Geus, J. W. (2012). The properties of amorphous nano-silica synthesized by the dissolution of olivine. Chemical Engineering Journal, 211-212, 112-121.

3. ISO 10426-1. (2009). Petroleum and natural gas industries - Cements and materials for well cementing - Part 1: Specification (pp. 1-38). ISO, Genève 20, CH-1211.

4. Van Breugel, K. (1991). Simulation of hydration and formation of structure in hardening cement based materials (pp. 1-295). PhD thesis, Delft University of Technology, Delft.

5. Poole, J. L., Riding, K. A., Folliard, K. J., Juenger, M. C., \& Schindler, A. K. (2007). Methods for calculating activation energy for Portland cement. American Concrete Institute (ACI) Materials Journal, 104(1), 303-311.

6. Waller, V., de Larrard, F., \& Roussel, P. (1996). Modeling the temperature rise in massive HPC Structures. Proceedings 4th international symposium on Utilization of High-strength/Highperformance Concrete, Paris, pp. 415-421.

7. Glasstone, S., Laidler, K. J., \& Eyring, H. (1941). The theory of rate processes. New York: McGraw-Hill.

8. Kada-Benameur, H., Wirquin, E., \& Duthoit, B. (2000). Determination of apparent activation energy of concrete by isothermal calorimetry. Cement and Concrete Research, 30(2), 301-305.

9. Levenspiel, O. (1999). Chemical reaction engineering (3rd ed., pp. 1-684). New York: Wiley. 
10. Bullard, J. W., Jennings, H. M., Livingston, R. A., Nonat, A., Scherer, G. W., Schweitzer, J. S., Scrivener, K. L., \& Thomas, J. J. (2011). Mechanisms of cement hydration. Cement and Concrete Research, 41, 1208-1223.

11. Thomas, J. J. (2012). The instantaneous apparent activation energy of cement hydration measured using a novel calorimetry-based method. Journal of the American Ceramic Society, 95, 3291-3296. 